\title{
Monoclonal antibody recognition of members of the meningococcal P1.10 variable region family: implications for serological typing and vaccine design
}

\author{
Janet Suker, Ian M. Feavers and Martin C. J. Maiden \\ Author for correspondence: Martin C. J. Maiden. Tel: +44 1707 654753. Fax: +44 1707646730. \\ e-mail: mmaiden@nibsc.ac.uk
}

Division of Bacteriology, National Institute for Biological Standards and Control, Blanche Lane, South Mimms, Potters Bar, Herts EN6 3QG, UK
Identification of antigenic variants of the PorA protein of Neisseria meningitidis with specific mAbs (serosubtyping) is used in meningococcal strain characterization and the resultant data has been exploited in the design of novel multivalent vaccines against this important pathogen. The reactivity of the P1.10 serosubtyping mAb MN20F4.17 with eight members of the meningococcal P1.10 variable region (VR) family (prototype P1.10 and variants P1.10a-P1.10g), identified by nucleotide sequence analysis of porA genes, was investigated. Analysis of overlapping synthetic octapeptides by ELISA demonstrated that the peptide sequence, QNQRPTL, present only in the prototype P1.10, was sufficient for binding of the mAb. A linear peptide of 14 amino acids, containing the minimum epitope, inhibited binding of $\mathrm{mAb}$ MN20F4.17 to whole cells in a competitive ELISA. This binding was weak compared with a tethered peptide or the native protein. In whole-cell ELISA or dot-blot assays using low concentrations of mAb MN20F4.17 only the prototype P1.10 was detected. However, when higher concentrations of antibody were used the prototype P1.10 was detected, together with variants $P 1.10 a, P 1.10 \mathrm{C}$ and P1.10e by whole-cell ELISA and P1.10a and P1.10C by the immunoblot technique. The variants P1.10b, P1.10d, P1.10f and P1.10g showed no reactivity with mAb under any of the conditions tested. A survey of the porA genes in serogroup $B$ and $C$ strains revealed that the $P 1.10$ a variant, rather than the prototype P1.10, was the most common member of the P1.10 VR family in England and Wales. These data illustrate: (i) the problems associated with epidemiological analyses that rely solely on monoclonal antibodies; (ii) the importance of using defined assay conditions for serosubtyping; and (iii) that genetical analyses provide more reliable information than serological data based on murine reagents for the design of candidate vaccines that include PorA.

Keywords: Neisseria meningitidis, PorA, monoclonal antibody, serosubtyping, antigenic variation

\section{INTRODUCTION}

Bacterial meningitis and septicaemia, caused by the human pathogen Neisseria meningitidis, are characterized by rapid onset and a high mortality rate (Peltola, 1983; Bannister, 1988; Hart \& Rogers, 1993). The management of these

Abbreviation: VR, variable region diseases, which affect only a small proportion of meningococcal carriers, requires swift diagnosis and comprehensive surveillance (Broome, 1986; Schwartz et al., 1989; Caugant et al., 1994). Murine $\mathrm{mAbs}$ are employed for the routine epidemiological characterization of meningococci by the identification of antigenic variants of the PorA protein, a porin (Abdillahi \& Poolman, 1987, 1988a). This protein is also a major component of several antimeningococcal vaccines included in clinical trials (Fine, 
1991; Sierra et al., 1991; van der Ley et al., 1995). However, many isolates fail to react with the current set of $\mathrm{mAbs}$ and new approaches are required to identify these strains for epidemiological analysis and to provide data for vaccine design and assessment.

The application of molecular techniques, such as direct nucleotide sequence determination, permits the characterization of meningococcal PorA variants by deduced amino acid sequence rather than by antibody reactivity (Suker et al., 1994). The term 'subtype' is best used to refer to PorA proteins characterized by the deduction of their amino acid sequences from nucleotide sequence data and 'serosubtype' to indicate characterization solely by mAbs. Comparative and immunological studies have shown that subtypes reside in two variable regions (VRs), designated VR1 and VR2, of PorA which correspond to surface loops I and IV of the proposed porin structure (Barlow et al., 1989; McGuinness et al., 1990, 1993; Butcher et al., 1991; van der Ley \& Poolman, 1991; van der Ley et al., 1991; Maiden et al., 1991; Suker et al., 1994). Distinct VR1 and VR2 peptide sequences are assigned arbitrary numbers and confer a dual subtype designation given after the prefix 'P1.', e.g. P1.5,10, where 5 is located in VR1 and 10 in VR2.

The accumulation of mutations in the subtype-encoding regions of the por $A$ gene results in VR 'families' that comprise related peptide sequences (Suker et al., 1994). The minor variants are distinguished by the addition of a lower case letter after the subtype designation; e.g., P1.10a. Continuous peptide epitopes within the subtype sequences that are recognized by the serosubtyping $\mathrm{mAbs}$ have been defined for a number of the VR families (McGuinness et al., 1990, 1993). However, small amino acid changes in the VR families may result in the loss or sequestration of these epitopes in some variants (McGuinness et al., 1991, 1993; Wedege et al., 1993).

The present work was undertaken to define the reactivity of members of the P1.10 VR family with serosubtyping $\mathrm{mAb}$ MN20F4.17. The P1.10 family was chosen as it is widely distributed in meningococci and the prototype P1.10 sequence is included in a multivalent PorA vaccine (van der Ley et al., 1995). The minimum amino acid sequence recognized by the $\mathrm{P} 1.10$ serosubtyping $\mathrm{mAb}$ MN20F4.17 was defined and the immunological reactivities of this antibody with eight members of the P1.10 VR family were compared by ELISA and immunoblotting. The relative contributions of amino acid sequence and epitope conformation in serosubtype recognition were investigated by immunoassay of membrane preparations subjected to boiling in SDS and by a competitive ELISA of a linear peptide with protein in its native conformation. Finally, the distribution of members of the P1.10 VR family among serotyped P1.10 and nonserotypeable serogroup $\mathrm{B}$ and $\mathrm{C}$ strains was determined by comparative analyses of por $A$ genes. These data show that for the P1.10 VR family serosubtyping with $\mathrm{mAb}$ underestimates the antigenic diversity of PorA. We conclude that multivalent PorA vaccines designed on the basis of serosubtype data alone may not necessarily contain the most appropriate variant of a given VR family.

\section{METHODS}

Bacterial strains. Meningococcal strains used in this study were provided by the Public Health Laboratory, Withington Hospital, Manchester and by the Max-Planck Institut für molekulare Genetik, Berlin. The nine strains in Table 1 were identified in surveys of 288 meningococcal isolates ( 55 strains in Suker $e t$ al., 1994; 233 strains in I. M. Feavers, A. J. Fox, S. Gray, D. M. Jones, J. Suker \& M. C. J. Maiden, unpublished results). The strains from these surveys were also used for the assessment of por $A$ diversity. Strain Z1388 was chosen as a negative control strain as its por $A$ gene is identical to that encoding the prototype P1.10 (Z1040) except for an 87 bp deletion which removes VR2 (Suker et al., 1994). The VR2 sequences of the eight P1.10 variant strains were confirmed by direct nucleotide sequence analysis prior to this study using the method of Suker et al. (1994). The expression of the por $A$ gene by each of the nine strains was tested by separation of membrane protein samples by SDS-PAGE. All of the strains produced a PorA protein visible by Coomassie Brilliant Blue staining. A further 13 recent clinical isolates of serosubtype P1.10, serogroup B and C strains (strain numbers, 2651-2663) were obtained from the Public Health Laboratory, Manchester and were unique to this study.

Propagation of meningococcal strains and preparation of DNA. Meningococcal strains (Table 1), were maintained at $-70{ }^{\circ} \mathrm{C}$ in Müller-Hinton broth with $50 \%(\mathrm{v} / \mathrm{v})$ 'freezing mix' [10\% (v/v) glycerol; $3 \mathrm{mM}$ sodium citrate; $1 \mathrm{mM}$ ammonium sulphate; $1 \mathrm{mM}$ magnesium sulphate; $100 \mathrm{mM}$ potassium phosphate, $\mathrm{pH} \mathrm{6.6]}$. The bacteria were propagated on heated blood (chocolate) agar at $37^{\circ} \mathrm{C}$ in a $5 \%(\mathrm{v} / \mathrm{v}) \mathrm{CO}_{2}$ atmosphere for 8-16 h. Preparation of DNA from meningococcal strains was performed using an Isoquick Kit (MicroProbe) by the rapid DNA extraction protocol provided by the manufacturer. Cells were suspended in $500 \mu \mathrm{l}$ sample buffer (MicroProbe) to approximately $10^{8}$ cells $\mathrm{ml}^{-1}$. Larger scale preparation of DNA was done by scraping the growth from five chocolate agar plates and resuspending the bacteria in $5 \mathrm{ml} \mathrm{TE}$ buffer $(10 \mathrm{mM}$ Tris/ $\mathrm{HCl}$ containing $1 \mathrm{mM}$ EDTA, $\mathrm{pH} 8 \cdot 0$ ) to which $5 \mathrm{ml}$ $100 \mathrm{mM}$ Tris $/ \mathrm{HCl}, \mathrm{pH} \mathrm{7.5}$, containing $100 \mathrm{mM} \mathrm{NaCl}, 10 \mathrm{mM}$ EDTA and $1 \%$ (v/v) Sarkosyl was added. Proteinase $K$ was added to a final concentration of $100 \mu \mathrm{g} \mathrm{ml}^{-1}$ and the samples were incubated at $55^{\circ} \mathrm{C}$ for $2 \mathrm{~h}$. The mixture was then extracted once with phenol, once with phenol/chloroform and once with chloroform. Boiled RNase A (final concentration $100 \mu \mathrm{g} \mathrm{ml}^{-1}$ ) was added to the extract which was incubated at room temperature for $2 \mathrm{~h}$. The samples were again extracted with phenol, phenol/chloroform and chloroform and dialysed overnight against two changes of $0.1 \times$ TE buffer. The DNA concentration and purity were estimated spectrophotometrically before use.

PCR. Reaction components were as follows: $50 \mathrm{ng}$ template DNA $\mu^{-1} ; 10 \mathrm{mM}$ Tris/ $\mathrm{HCl}, \mathrm{pH} 8.0 ; 50 \mathrm{mM} \mathrm{KCl} ; 1.5 \mathrm{mM}$ $\mathrm{MgCl}_{2} ; 0.001 \%$ gelatin; $200 \mu \mathrm{M}$ of each of dATP, dCTP, dGTP and dTTP; $2 \mu \mathrm{M}$ of each of the required primers and $0.5 \mathrm{U}$ Taq polymerase (Amplitaq, Cetus). The components were incubated for 30 cycles in a programmable heat block (PHC-2, Techne Instruments) for $2 \mathrm{~min}$ at $94^{\circ} \mathrm{C}, 2 \mathrm{~min}$ at $68^{\circ} \mathrm{C}$ or $70^{\circ} \mathrm{C}$ and $3 \mathrm{~min}$ at $72^{\circ} \mathrm{C}$. At the end of 30 cycles, the reaction mixtures were incubated for $3 \mathrm{~min}$ at $72{ }^{\circ} \mathrm{C}$.

Gene fingerprinting by chain termination. Fingerprints from PCR products were produced by the method of Suker et al. (1994). Dideoxy termination reactions were run on adjacent tracks of polyacrylamide gels and compared. For example, 'T- 
Table 1. Characteristics of nine N. meningitidis strains used in this study

Serogroup, serotype and serosubtype assigned at source. NT, Not typable.

\begin{tabular}{|c|c|c|c|c|c|c|c|}
\hline $\begin{array}{l}\text { Strain } \\
\text { number }\end{array}$ & $\begin{array}{c}\text { Country of } \\
\text { isolation }\end{array}$ & Source* & Serogroup $\dagger$ & Serotype & Serosubtype $\ddagger$ & Subtype $₫$ & $\begin{array}{c}\text { Deduced amino acid } \\
\text { sequence in VR2 of P1.10 } \\
\text { subtype variant }\end{array}$ \\
\hline Z1040 & Morocco & MPIG & A & 4,21 & $\mathrm{P} 1.10$ & $5 c, 10$ & HFVQNKQNQRPTLVP \\
\hline 2400 & UK (Epsom) & PHL & $\mathrm{C}$ & $2 \mathrm{~b}$ & NT & $5 a, 10 a$ & HFVQNKQNQPPTLVP \\
\hline 2401 & UK (Romford) & PHL & NG & NT & NT & $5,10 \mathrm{~b}$ & HFVQDKKGQPPTLVP \\
\hline 2376 & UK (Brighton) & PHL & $\mathrm{C}$ & $2 \mathrm{a}$ & NT & $5,10 \mathrm{c}$ & HFVQNKQNQQPTLVP \\
\hline Z4272 & USA & MPIG & $\mathrm{C}$ & $2 \mathrm{a}$ & $\mathrm{P} 1.5,2$ & $5 \mathrm{a}, 10 \mathrm{~d}$ & HFVQNKQNKQNQPPTLVP \\
\hline Z4063 & China & MPIG & A & 4 & NT & $7 \mathrm{c}, 10 \mathrm{e}$ & HFVQNKQSQRPTLVP \\
\hline 2403 & UK (Broadgreen) & PHL & NG & NT & NT & $5 a, 10 f$ & HFVQNKQNQQNQQNQPPTLVP \\
\hline 2413 & UK (Rhyll) & PHL & $\mathrm{B}$ & NT & P1.5 & $5,10 \mathrm{~g}$ & HFVQNKQNKPPTLVP \\
\hline Z1388 & Algeria & MPIG & A & 4,21 & NT & $5 c$, del & Deleted \\
\hline
\end{tabular}

* MPIG, Max-Planck Institut für molekulare Genetik (courtesy of Dr M. Achtman); PHL, Manchester Public Health Laboratory (courtesy of Dr A. J. Fox).

$\dagger$ NG, Not groupable.

$\ddagger$ Determined by reactivity with $\mathrm{mAb}$.

\$VR loop names, defined by nucleotide sequence analysis (Suker et al., 1994; I. M. Feavers, A. J. Fox, S. Gray, D. M. Jones, J. Suker \& M. C. J. Maiden, unpublished results).

track ' fingerprints were produced by running dideoxythymidine reactions in adjacent lanes. Separate fingerprints were determined for extension reactions terminated with dideoxythymidine, dideoxyguanine and dideoxycytosine.

Membrane preparation and protein analysis. Membranes of $N$. meningitidis were prepared by a modification of the sphaeroplast lysis method (Witholt et al., 1976). A single colony from a chocolate agar plate was inoculated into $5 \mathrm{ml}$ Müller-Hinton broth and grown for $6 \mathrm{~h}$ at $37^{\circ} \mathrm{C}$ until an $\mathrm{OD}_{600}$ of 0.6 (approx. $5 \times 10^{8}$ cells $\mathrm{ml}^{-1}$ ) was obtained. Cells from $4 \mathrm{ml}$ culture were harvested and resuspended in $200 \mu \mathrm{l} 200 \mathrm{mM}$ Tris/ $\mathrm{HCl}$ containing $1 \mathrm{mM}$ EDTA, $\mathrm{pH} \mathrm{8.0.} \mathrm{To} \mathrm{this} \mathrm{suspension} \mathrm{was} \mathrm{added}$ $200 \mu \mathrm{l} 200 \mathrm{mM}$ Tris $/ \mathrm{HCl}$ containing $1 \mathrm{M}$ sucrose and $1 \mathrm{mM}$ EDTA. After mixing for $90 \mathrm{~s}, 24 \mu \mathrm{g}$ egg white lysozyme was added followed by $400 \mu$ l deionized water after a further $45 \mathrm{~s}$. The suspension was incubated at room temperature with gentle mixing for $30 \mathrm{~min}$. The sphaeroplasts formed were collected by centrifugation at $40000 \mathrm{~g}$ for $20 \mathrm{~min}$ at $20^{\circ} \mathrm{C}$, and lysed by the addition of $800 \mu \mathrm{l}$ ice-cold deionized water. The membranes were collected by centrifugation as above and resuspended in $400 \mu \mathrm{l}$ deionized water. Protein concentrations were estimated by the bicinchoninic acid method using reagents from a BCA kit (Pierce) with BSA as a standard. Membrane proteins were separated on a $12.5 \%(\mathrm{w} / \mathrm{v})$ acrylamide gel and visualized by staining with Coomassie Brilliant Blue.

Source of mAb MN20F4.17. The mAb was used in the form of ascitic fluid, collected from pristane-treated mice after intraperitoneal injection with cells of the hybridoma cell line MN20F4.17, provided by Dr J. T. Poolman of the National Institute for Public Health and Environmental Protection, Bilthoven, The Netherlands (Poolman et al., 1995). Ascitic fluid was stored at $-20^{\circ} \mathrm{C}$. Purified antibody was obtained from the ascitic fluid by precipitation with $45 \%(\mathrm{w} / \mathrm{v})$ ammonium sulphate solution followed by separation on a protein $\mathrm{G}$ column.

ELISA. ELISAs were carried out by a modified version of the method of Abdillahi \& Poolman (1987). Chocolate agar plates were spread with $100 \mu \mathrm{l}$ cells from frozen stocks and incubated at $37^{\circ} \mathrm{C}$ in $5 \% \mathrm{CO}_{2}$ atmosphere overnight. For each strain, $5 \mathrm{ml}$ Müller-Hinton broth was inoculated and incubated at $37^{\circ} \mathrm{C}$ in a shaking incubator for $8 \mathrm{~h}$ or until an $\mathrm{OD}_{600}$ of 0.6 was obtained. Cells were harvested from $3 \mathrm{ml}$ broth culture by centrifugation for $10 \mathrm{~min}$ in a microfuge and resuspended in $1 \mathrm{ml}$ PBS containing $0.05 \%$ Tween 20 . The cell suspensions were heated at $55^{\circ} \mathrm{C}$ for $30 \mathrm{~min}$ to kill the cells and then diluted

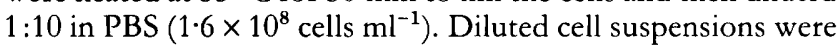
stored at $4{ }^{\circ} \mathrm{C}$ for up to $7 \mathrm{~d}$. For ELISA, Nunc 96-well flatbottomed microtitre plates were freshly coated for each test with $100 \mu \mathrm{l}$ per well of the cell suspension and allowed to dry at $37^{\circ} \mathrm{C}$ overnight. The plates were washed three times with $0.025 \%$ Tween 20. Decimal dilutions of mAb MN20F4.17 (100 $\mu \mathrm{l}$ per well) were added to the plate which was incubated at $37{ }^{\circ} \mathrm{C}$ for $1 \mathrm{~h}$. The plate was again washed three times with $0.025 \%$ Tween 20. Secondary conjugate (Protein A-peroxidase, $100 \mu \mathrm{l}$ per well) diluted $1: 2500$ in PBS containing $0.5 \%$ BSA and $0.01 \%$ Tween 20 , was added and the plate incubated at $37^{\circ} \mathrm{C}$ for $1 \mathrm{~h}$. The plate was finally washed with $0 \cdot 025 \%$ Tween 20 . ABTS [2,2'-azino-bis(3-ethylbenzthiazoline-6-sulphonic acid) diammonium salt, $0.5 \mathrm{mg} \mathrm{ml}^{-1}$ ] was made up in $0.05 \mathrm{M}$ citric acid, $\mathrm{pH}$ 4.0 , containing $0.006 \%$ hydrogen peroxide and added to the plate $(150 \mu \mathrm{l}$ per well). The colour was allowed to develop for 10 min and the $A_{405}$ was measured. For the inhibition ELISA, $100 \mu \mathrm{l}$ aliquots of purified mAb MN20F4.17 (either 55 or $550 \mathrm{ng}$ $\mathrm{ml}^{-1}$ ) were mixed with $100 \mu \mathrm{l}$ aliquots $0-10 \mathrm{mg}$ peptide $\mathrm{ml}^{-1}$ before addition to the whole-cell-coated plate.

Dot-immunoblotting. Membrane samples were prepared as above and various dilutions made. For non-denatured samples, dilutions were made in PBS; for denatured samples, dilutions were made in transfer buffer minus methanol $25 \mathrm{mM}$ Tris $/ \mathrm{HCl}$ containing $0 \cdot 19 \mathrm{M}$ glycine and $0 \cdot 1 \% \mathrm{SDS}$ ] and boiled for $5 \mathrm{~min}$. A nitrocellulose membrane, presoaked in PBS, was placed in a dot-blot manifold (Bio-Rad), $100 \mu$ l samples were applied to the wells and drawn on to the membrane under vacuum. The membrane was cut in half; the portion with non-denatured samples was rinsed in PBS, the portion with denatured samples was rinsed in transfer buffer containing $20 \%(\mathrm{v} / \mathrm{v})$ methanol to 
remove traces of SDS. Both filters were blocked in PBS containing $5 \%(\mathrm{w} / \mathrm{v})$ powdered milk for $1 \mathrm{~h}$ at $25^{\circ} \mathrm{C}$ and incubated for $16 \mathrm{~h}$ with dilutions of $\mathrm{mAb}$ MN20F4.17 in PBS/milk (usually 1:100). After rinsing in several changes of PBS, the filters were incubated for $1 \mathrm{~h}$ with Protein A-peroxidase conjugate, diluted $1: 1000$ in PBS/milk. Following further washes in PBS, dots were visualized by immersing the filters in $0.35 \mathrm{mM}$ 4-chloronaphthol in $16 \%$ methanol and $20 \mathrm{mM}$ Tris $/ \mathrm{HCl}, \mathrm{pH} 7 \cdot 4$.

Epitope scanning. A set of synthetic peptides was synthesized on the tips of derivatized polyethylene pins in the configuration of a 96-well microtitre plate using the Pin Technology method [Cambridge Research Biochemicals; Geysen et al. (1987)]. Each peptide was eight amino acids long and overlapped with the next consecutive peptide by seven amino acids. The synthesis schedule (General Net strategy) was designed so that all known variants of the P1.10 epitope were covered with an overlap of one amino acid. The peptide-bearing pins were blocked for $16 \mathrm{~h}$ in $2 \%(\mathrm{w} / \mathrm{v}) \mathrm{BSA}$ at $4{ }^{\circ} \mathrm{C}$ and then reacted in an ELISA with purified P1.10 antibody using $440 \mathrm{ng} \operatorname{IgG}$ per peptide. Antimouse $\operatorname{lgG}$-peroxidase conjugate was used as a secondary antibody and binding was detected with ABTS as a substrate. $A_{405}$ was measured and plotted against peptide sequence.

\section{RESULTS}

\section{P1.10 variants show different reactivities with $\mathrm{mAb}$ MN20F4.17}

The reactivities of nine meningococcal strains (Table 1) with mAb MN20F4.17 were assessed by ELISA and immunoblotting. When high concentrations of $\mathrm{mAb}$ MN20F4.17 were used (1:10 dilution of ascitic fluid containing $\mathrm{mAb}$ or $20 \mu \mathrm{g}$ purified IgG per well), strains expressing four of the variant Por A proteins examined, prototype P1.10, P1.10a, P1.10c and P1.10e, bound antibody at levels detectable in whole-cell ELISA. At lower antibody concentrations only strain Z1040, expressing the prototype P1.10, bound antibody at levels detectable by this assay (Fig. 1).

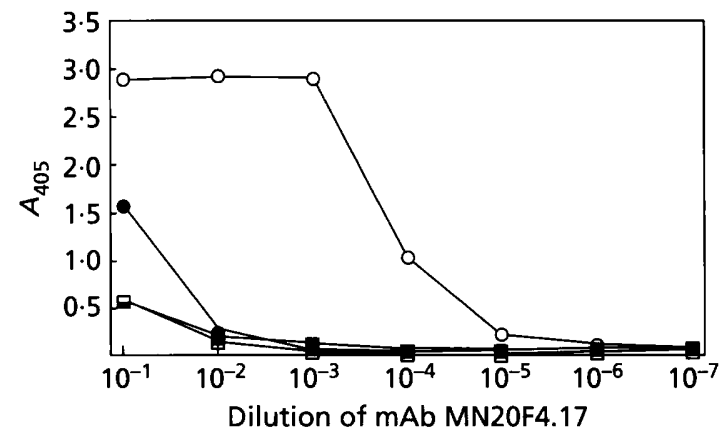

Fig. 1. Detection of P1.10 variants by whole-cell ELISA using mAb MN20F4.17. Mean absorbance readings from duplicate samples are plotted against dilutions of ascitic fluid containing mAb MN20F4.17 binding to cells expressing the prototype P1.10 $(O)$ and each of the variants P1.10a (O), P1.10c $(\square)$ and P1.10e $(\square)$. The background reading from mAb-binding to whole cells of the P1.10-deleted negative control strain (Z1388) has been subtracted, hence variants P1.10b, P1.10d, P1.10f and P1.10g do not appear on the graph as binding to these strains was not above background levels under these conditions.

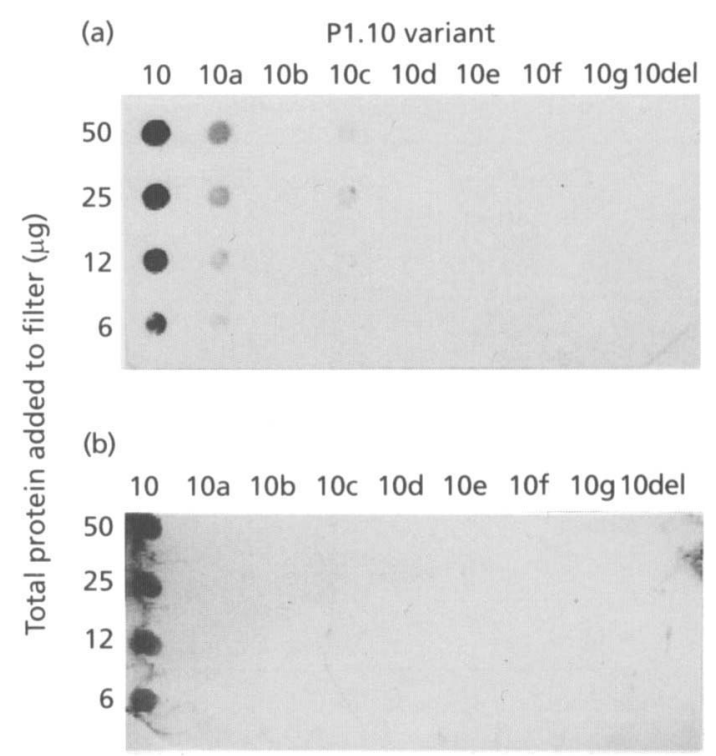

Fig. 2 Immunoblot of members of the P1.10 variable region family with the P1.10 specific mAb, MN20F4.17. Filters were prepared in a dot-blot manifold using doubling dilutions of membrane samples $(6-50 \mu \mathrm{g}$ total protein per dot) from strains expressing PorA proteins with the prototype $\mathrm{P} 1.10$ and variants P1.10a-P1.10g. (a) Non-denaturing conditions, PBS was used for dilution of samples and to wash the filter following transfer; (b) denaturing conditions, SDS-containing buffer was used for dilution and boiling of samples and to wash the filter following transfer. Each filter was probed with ascitic fluid containing mAb MN20F4.17 at a dilution of 1:100.

Immunoblotting experiments showed that $\mathrm{mAb}$ MN20F4.17 bound to native membrane samples of strains expressing the prototype P1.10, P1.10a and P1.10c, although the signals obtained with the variant strains were weaker than that obtained with the prototype strain (Fig. 2a). When membrane samples boiled in SDScontaining buffer were used, only membranes from the strain expressing the prototype P1.10 sequence reacted with the antibody at detectable levels (Fig. 2b).

In whole-cell ELISA, the prototype P1.10 was detected by up to $1: 10000$ dilution of ascitic fluid (Fig. 1) or $2 \mathrm{ng}$ purified IgG per well (data not shown). The P1.10 variants which differed from the prototype P1.10 by only one amino acid (P1.10a, P1.10c and P1.10e) were only reliably detected at $1: 10$ dilution of mAb MN20F4.17. Four variants were never detected by the $\mathrm{mAb}$; these differed from the prototype sequence by either two (variant P1.10g), four (variants P1.10b and P1.10d) or seven (variant P1.10f) amino acids (Table 1).

\section{Amino acid sequence QNQRPTL identified as the minimum $P 1.10$ epitope reactive with $\mathrm{mAb}$ MN20F4.17}

The minimum amino acid sequence responsible for the P1.10 epitope was defined by means of a set of overlapping peptides synthesized on the tips of polyethylene pins. Based on the amino acid sequences of the eight variants of 


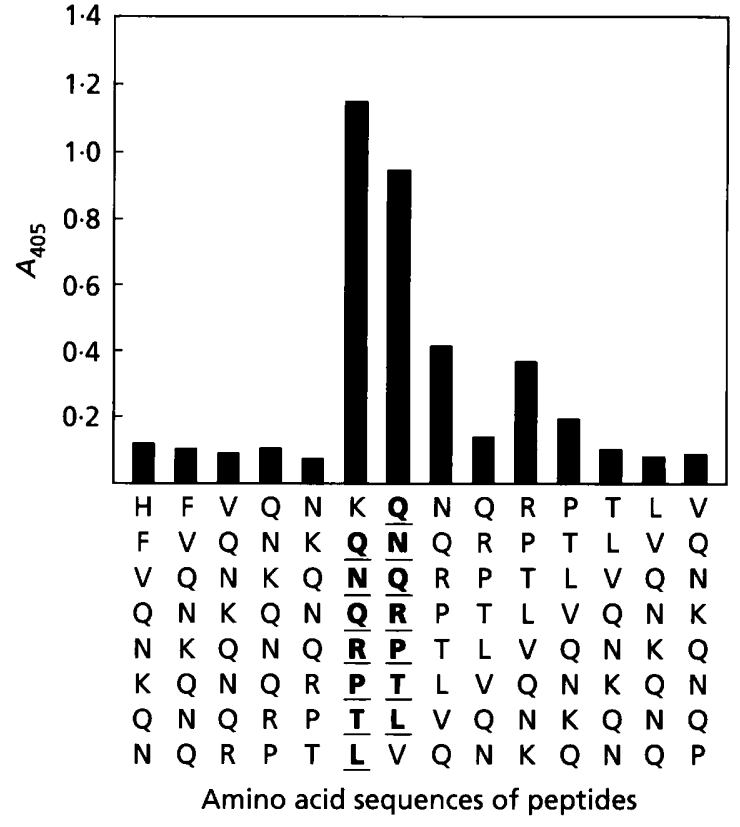

Fig. 3. Localization of the minimum epitope required for $\mathbf{P} 1.10$ subtype specificity of mAb MN20F4.17. A set of tethered overlapping synthetic peptides of eight amino acids in length, differing by one amino acid and based on the sequences of the eight P1.10 variants, were reacted in ELISA with purified P1.10 antibody using $440 \mathrm{ng}$ IgG per peptide. The amino acid sequences of the peptides (printed vertically) which showed greatest reactivity are plotted against $A_{405}$. The putative minimum epitope sequence is shown in bold and underlined.

the P1.10 VR family, 91 peptides of eight amino acids in length, overlapping by seven amino acids, were synthesized. The last two amino acids (VP) of the P1.10 VR were omitted from the synthesis schedule as these occur in all variants and it was assumed that they did not contribute to the minimum epitope. The peptide-bearing pins were reacted in ELISA with mAb MN20F4.17 (Fig. 3). The ELISA profile showed that most reactivity with the antiP1.10 antibody occurred with the peptide of sequence KQNQRPTL and comparison with the other peptides showed that the sequence QNQRPTL was sufficient for binding of $\mathrm{mAb}$ MN20F4.17.

\section{Binding of mAb MN20F4.17 is inhibited by a synthetic $P 1.10$ peptide}

The reactivity of $\mathrm{mAb} \mathrm{MN} 20 \mathrm{~F} 4.17$ with a synthetic 14amino-acid peptide was evaluated. The sequence of this peptide, HFVQNKQNQRPTLV, corresponded to the prototype P1.10 VR but lacked the terminal proline. The peptide did not react in ELISA when dried on to plates or in immunoblots when dot-blotted on to nitrocellulose filters, preventing a direct comparison of the binding of the peptide with whole cells of strain Z1040 to $\mathrm{mAb}$ MN20F4.17. Recognition of the peptide by $\mathrm{mAb}$ $\mathrm{MN} 20 \mathrm{~F} 4.17$ was demonstrated by using increasing amounts of the 14-amino-acid peptide with pure P1.10 antibody in a whole-cell competitive ELISA. The peptide inhibited $\mathrm{mAb}$ binding to whole cells at greater than $1 \mathrm{mg}$

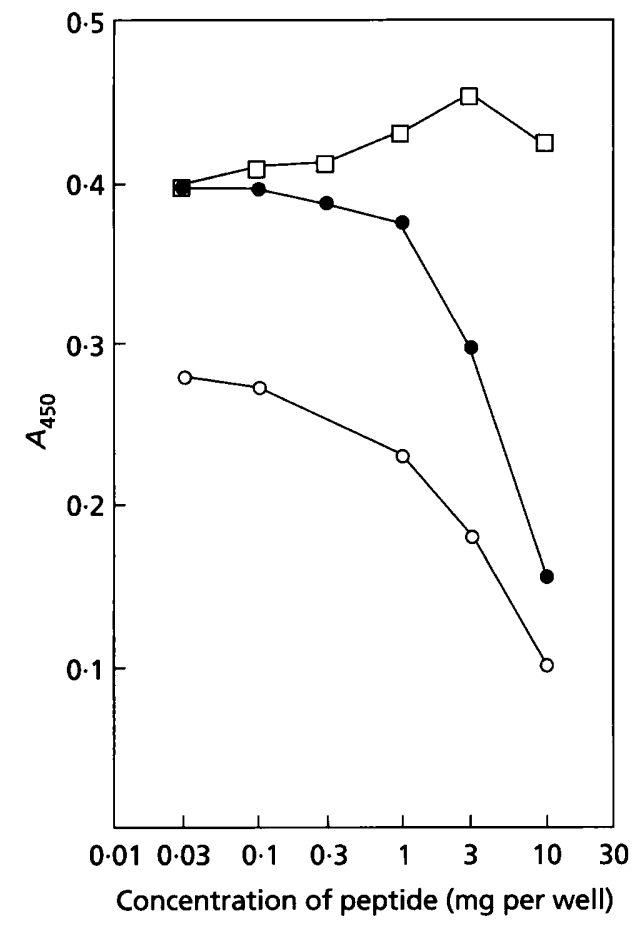

Fig. 4. Competitive-binding ELISA between whole cells of the P1.10 VR strain and its synthetic VR peptide for mAb MN20F4.17. A synthetic peptide of amino acid sequence HFVQNKQNQRPTL, corresponding to the prototype P1.10 subtype, inhibited binding of mAb MN2OF4.17 to whole cells of strain Z1040 expressing PorA containing the prototype P1.10 VR, whereas a negative control peptide of sequence CGPIKNKMSESPNKT (part of diphtheria toxin fragment DTB1) did not. Increasing concentration of each peptide is plotted against the mean absorbance readings from duplicate wells. O. Dilutions of P1.10 peptide with $55 \mathrm{ng}$ mAb per well; $O$, dilutions of P1.10 peptide with $5.5 \mathrm{ng}$ mAb per well; $\square$, dilutions of negative control peptide with $55 \mathrm{ng}$ mAb per well.

peptide per well (Fig. 4). The very high concentration of peptide required to out-compete the whole cells for binding to $\mathrm{mAb}$ suggested that the effect may be nonspecific. However, a different synthetic 15-amino-acid peptide (part of diphtheria toxin fragment DTB1 with the amino acid sequence CGPIKNKMSESPNKT) did not inhibit binding of $\mathrm{mAb}$ MN20F4.17 to whole cells of strain Z1040 at concentrations up to $10 \mathrm{mg}$ per well (Fig. 4).

\section{Identification of variation in the P1.10 family by chain termination fingerprinting}

The part of the por $A$ gene encoding VR2 was examined by chain termination fingerprinting in the following clinical isolates: (i) 30 strains which had been shown to possess por $A$ genes that encoded members of the P1.10 VR family by DNA hybridization (I. M. Feavers, A. J. Fox, S. Gray, D. M. Jones, J. Suker \& M. C. J. Maiden, unpublished results) but which failed to react with $\mathrm{mAb}$ MN20F4.17 and (ii) 13 recent isolates of strains serosubtyped by the Public Health Laboratory, Withington Hospital, Manchester as P1.10 using dot-blot with mAb 
MN20F4.17. From the 30 strains that did not react with the $\mathrm{mAb}, 10$ strains contained the prototype P1.10, 13 were P1.10a, four were P1.10c, one was P1.10d and two were P1.10f. Expression of PorA was not examined in these strains and therefore lack of expression remains an explanation of the failure of $\mathrm{mAb} \mathrm{MN} 20 \mathrm{~F} 4.17$ to detect them. The 13 recent isolates of serosubtyped $\mathrm{P} 1.10$ strains all encoded a prototype P1.10 VR with one exception which was P1.10d.

\section{DISCUSSION}

There are two levels of antigenic variation of PorA: (i) distinct subtype families in both VR1 and VR2 and (ii) variation within these VR families. The biology of this variation has implications for the use of PorA as a target for epidemiological characterization and as a vaccine component. The application of $\mathrm{mAb}$ reagents was a major advance in the identification of PorA variants by serosubtyping (Abdillahi \& Poolman, 1987, 1988a, b), and provided a degree of specificity and reproducibility that was difficult to achieve with polyclonal sera. However, molecular analyses of the por $A$ gene have identified subtype variants not detected by the serosubtyping mAbs. The amino acid changes that distinguish members of PorA VR families result in different reactivities with serosubtyping mAbs (McGuinness et al., 1991, 1993; Wedege et al., 1993; Suker et al., 1994). In some cases, these changes alter the minimum epitope sequence deduced from overlapping peptide experiments, a single amino acid change being sufficient to reduce or abolish antibody binding (McGuinness et al., 1991). In other cases, the minimum linear epitope is still present in Por A proteins that do not bind the antibody, but the relative position of the peptide sequence has been altered by the insertion or deletion of amino acids (Wedege et al., 1993). It has been proposed that the serosubtyping mAbs recognize a defined minimum peptide sequence as an epitope only when it is located at the apex of the putative loop formed by the VR (McGuinness et al., 1993). Displacement of the minimum peptide sequence from the apex of the loop hence destroys the epitope.

This analysis of the reactivity of eight members of the P1.10 VR family illustrates the effects of naturally occurring Por A variant sequences on $\mathrm{mAb}$ recognition. The epitope recognized by the $\mathrm{P} 1.10$ serosubtyping $\mathrm{mAb}$ MN20F4.17 comprises the peptide sequence QNQRPTL and only PorA proteins with this sequence bind the antibody well. However, the following evidence suggests that the conformation in which the minimum epitope is presented also affects binding. The antibody can bind weakly to other variants which lack the minimum peptide sequence and this binding is abolished by boiling the variant proteins in SDS. A tethered peptide binds to the $\mathrm{mAb}$ well but the linear synthetic peptide in solution binds poorly. However, the fact that a linear peptide can bind to the antibody in solution means that further biochemical studies of the interaction of the antibody and peptide by Fab-peptide co-crystallization and NMR are possible.
These observations are inconsistent with the results of Brooks et al. (1995) who have reported other variants of P1.10 that do react with the serosubtyping $\mathrm{mAb}$ under routine assay conditions but do not contain the peptide sequence QNQRPTL. These variants, designated P1.10h, $\mathrm{P} 1.10 \mathrm{i}$ and $\mathrm{P} 1.10 \mathrm{j}$ are unusual in that they contain residues (tryptophan and alanine) that do not occur in the other P1.10 variants and are uncommon in all PorA VR2 loops. In addition, these variants did not occur in 301 serogroup $\mathrm{A}, \mathrm{B}$ and $\mathrm{C}$ meningococci 233 strains from I. M. Feavers, A. J. Fox, S. Gray, D. M. Jones, J. Suker \& M. C. J. Maiden, unpublished results; 55 strains in Suker et al. (1994) and 13 strains in the present study], examined in this laboratory. A limited range of subtype families in VR1 are found in combination with P1.10, the P1.5 family being most common. The P1.10 variant strains reported by Brooks et al. (1995) contain a variant of the P1.5 family (P1.5b) in five strains and a novel prototype VR1 (P1.29) in two strains which have not previously been reported in combination with P1.10 variants. It is possible that these peptide sequences alter the conformation of PorA enabling the variants P1.10h, P1.10i and P1.10j to bind to mAb MN20F4.17.

A comprehensive childhood vaccine against meningococci has yet to be developed (Frasch, 1985, 1989; Sanborn, 1987; Fine, 1991; Milagres et al., 1994) and numerous protein antigens, including PorA, have been used as candidate vaccine components. Given the antigenic diversity of PorA, these vaccines must be multivalent if they are to protect against different meningococcal strains. The composition of such vaccines depends on accurate strain characterization to determine the diversity of the target antigen. A successful vaccine also requires information on the human response to these components. Although serological typing may have a role in the elucidation of these factors, there are several problems associated with the design of vaccines on the basis of data obtained with murine mAbs. First, serosubtyping can underestimate the antigenic diversity of PorA because members of a VR family react unpredictably with a given serosubtyping $\mathrm{mAb}$. Consequently, accurate interpretation of serosubtyping data is dependent on the definition of the binding properties of the serosubtyping $\mathrm{mAbs}$ and on the standardization and control of assay conditions. Secondly, the 'prototype' VR sequence, used to raise the antibody may not be representative of the subtypes found in the meningococcal population. For example, the P1.10a variant occurs more frequently than the prototype $\mathrm{P} 1.10$ in serogroup B and C strains. In addition, there is evidence that the epitopes identified by murine $\mathrm{mAbs}$ are not the same as the epitopes which are important in the human protective immune response (Delvig et al., 1994). Finally, it is likely that the epitopes within the circulating meningococcal population may change over time due to immune selection following carriage in humans.

\section{ACKNOWLEDGEMENTS}

We would like to thank Dr A. J. Fox and Dr M. Achtman for provision of meningococcal strains, Dr J. P. Derrick for 
provision of the P1.10 synthetic peptide and Dr D. Sesardic and Mrs C. Dawes for provision of the DTB1 peptide and advice on epitope mapping. We are grateful to Dr M. J. Corbel and Dr G. Schild for critically reading the manuscript.

\section{REFERENCES}

Abdillahi, H. \& Poolman, J. T. (1987). Whole-cell ELISA for typing Neisseria meningitidis with monoclonal antibodies. FEMS Microbiol Lett 48, 367-371.

Abdillahi, H. \& Poolman, J. T. (1988a). Definition of meningococcal class 1 OMP subtyping antigens by monoclonal antibodies. FEMS Microbiol Immunol 1, 139-144.

Abdillahi, H. \& Poolman, J. T. (1988b). Neisseria meningitidis group $B$ serosubtyping using monoclonal antibodies in whole-cell ELISA. Microb Pathog 4, 27-32.

Bannister, B. (1988). Clinical aspects of meningococcal disease. J Med Microbiol 26, 161-163.

Barlow, A. K., Heckels, J. E. \& Clarke, I. N. (1989). The class 1 outer membrane protein of Neisseria meningitidis: gene sequence and structural and immunological similarities to gonococcal porins. Mol Microbiol 3, 131-139.

Brooks, J. L., Fallon, R. J. \& Heckels, J. E. (1995). Sequence variation in class 1 outer membrane protein in Neisseria meningitidis isolated from patients with meningococcal infection and close household contacts. FEMS Microbiol Lett 128, 145-150.

Broome, C. V. (1986). The carrier state: Neisseria meningitidis. $J$ Antimicrob Chemother 18, Suppl. A, 25-34.

Butcher, S. J., Omar, P. J., Sarvas, M. \& Runeberg-Nyman, K. (1991). Sequence comparisons of the class 1 genes from Neisseria meningitidis strains and a folding model of the class 1 protein. In Neisseria 1990, pp. 193-198. Edited by M. Achtman, P. Kohl, C. Marchal, G. Morelli, A. Seiler \& B. Thiesen. Berlin: Walter de Gruyter.

Caugant, D. A., Høiby, E. A., Magnus, P., Scheel, O., Hoel, T., Bjune, G., Wedege, E., Eng, J. \& Frøholm, L. O. (1994). Asymptomatic carriage of Neisseria meningitidis in a randomly sampled population. J Clin Microbiol 32, 323-330.

Delvig, A., Jahn, S., Kusecek, B., Heckels, J. E., Rosenqvist, E., Høiby, E. A., Michaelsen, T. E. \& Achtman, M. (1994). A comparison of human and murine monoclonal IgGs specific for the P1.7 PorA protein of Neisseria meningitidis. Mol Immunol 31, 1257-1267.

Fine, P. E. (1991). Meningococcal vaccine trial in Norway. Lancet 338, 1456-1457.

Frasch, C. E. (1985). Status of a group B Neisseria meningitidis vaccine. Eur J Clin Microbiol 4, 533-536.

Frasch, C. E. (1989). Vaccines for prevention of meningococcal disease. Clin Microbiol Rev 2, S134-S138.

Geysen, H. M., Rodda, S. J., Mason, T. J., Tribbick, G. \& Schoofs, P. G. (1987). Strategies for epitope analysis using peptide synthesis. $J$ Immunol Methods 102, 259-274.

Hart, C. A. \& Rogers, T. R. F. (1993). Meningococcal disease. J Med Microbiol 39, 3-25.

van der Ley, P., Heckels, J. E., Virji, M., Hoogerhout, P. \& Poolman, J. T. (1991). Topology of outer membrane proteins in pathogenic Neisseria species. Infect Immun 59, 2963-2971.

van der Ley, P. \& Poolman, J. T. (1991). The class 1 outer membrane protein of Neisseria meningitidis: prediction of topology and construction of a multivalent vaccine strain. In Neisseria 1990, pp. 193-198. Edited by M. Achtman, P. Kohl, C. Marchal, G. Morelli, A. Seiler \& B. Thiesen. Berlin: Walter de Gruyter. van der Ley, P., van der Biezen, J. \& Poolman, J. T. (1995). Construction of Neisseria meningitidis strains carrying multiple chromosomal copies of the por $A$ gene for use in the production of a multivalent outer membrane vesicle vaccine. Vaccine 13, 401-407.

McGuinness, B. T., Barlow, A. K., Clarke, I. N., Farley, J. E., Anilionis, A., Poolman, J. T. \& Heckels, J. E. (1990). Deduced amino acid sequences of class 1 protein PorA from three strains of Neisseria meningitidis. J Exp Med 171, 1871-1882.

McGuinness, B. T., Clarke, I. N., Lambden, P. R., Barlow, A. K., Poolman, J. T., Jones, D. \& Heckels, J. E. (1991). Point mutation in meningococcal por $A$ gene associated with increased endemic disease. Lancet 337, 514-517.

McGuinness, B. T., Lambden, P. R. \& Heckels, J. E. (1993). Class 1 outer membrane protein of Neisseria meningitidis: epitope analysis of the antigenic diversity between strains, implications for subtype definition and molecular epidemiology. Mol Microbiol 7, 505-514.

Maiden, M. C. J., Suker, J., McKenna, A. J., Bygraves, J. A. \& Feavers, I. M. (1991). Comparison of the class 1 outer membrane proteins of eight serological reference strains of Neisseria meningitidis. Mol Microbiol 5, 727-736.

Milagres, L. G., Ramos, S. R., Sacchi, C. T., Melles, C. E. A., Vieira, V. S. D., Sato, H., Brito, G. S., Moraes, J. C. \& Frasch, C. E. (1994). Immune response of Brazilian children to a Neisseria meningitidis serogroup B outer membrane protein vaccine: comparison with efficacy. Infect Immun 62, 4419-4424.

Peltola, H. (1983). Meningococcal disease: still with us. Rev Infect Dis 5, 71-91.

Poolman, J. T., Kriz Kuzemenska, P., Ashton, F., Bibb, W., Dankert, J., Demina, A., Frøholm, L. O., Hassan King, M., Jones, D. M., Lind, P., Prakash, K. \& Xujing, H. (1995). Serotypes and subtypes of Neisseria meningitidis: results of an international study comparing sensitivities and specificities of monoclonal antibodies. Clin Diagn Lab Immunol 2, 69-72.

Sanborn, W. R. (1987). Development of meningococcal vaccines. In Evolution of Meningococcal Disease, pp 121-134. Edited by N. A Vedros. Boca Raton, Florida: CRC Press.

Schwartz, B., Moore, P. S. \& Broome, C. V. (1989). Global epidemiology of meningococcal disease. Clin Microbiol Rev 2, S118-S124.

Sierra, V. G. G., Campa, C. H., Garcia, L. I., Sotolongo, F. P. Izquierdo, L. P., Valcarcel, M. N., Casanueva, V. G., Baro, M. S., Leguen, F. C., Rodriguez, R. C. \& Terry, H. M. (1991). Efficacy evaluation of the Cuban vaccine VA-MENGOC-BC against disease caused by serogroup B Neisseria meningitidis. In Neisseria 1990, pp. 193-198. Edited by M. Achtman, P. Kohl, C. Marchal, G. Morelli, A. Seiler \& B. Thiesen. Berlin: Walter de Gruyter.

Suker, J., Feavers, I. M., Achtman, M., Morelli, G., Wang, J.-F. \& Maiden, M. C. J. (1994). The por $A$ gene in serogroup A meningococci : evolutionary stability and mechanism of genetic variation. Mol Microbiol 12, 253-265.

Wedege, E., Dalseg, R., Caugant, D. A., Poolman, J. T. \& Frøholm, L. O. (1993). Expression of an inaccessible P1.7 subtype epitope on meningococcal class 1 proteins. J Med Microbiol 38, 23-28.

Witholt, B., Boekhout, M., Brock, M., Kingma, J., van Heerikhuizen, H. \& de Leij, L. (1976). An efficient and reproducible procedure for the formation of spheroplasts from variously grown Escherichia coli. Anal Biochem 74, 160-170.

Received 18 July 1995; revised 20 September 1995; accepted 28 September 1995. 